\title{
Culture and Moral Leadership in Education
}

\author{
Kam-cheung Wong \\ Peabody Journal of Education, Vol. 73, No. 2, Leading Schools in a Global Era: A Cultural \\ Perspective. (1998), pp. 106-125.
}

Stable URL:

http://links.jstor.org/sici?sici=0161-956X\%281998\%2973\%3A2\%3C106\%3ACAMLIE\%3E2.0.CO\%3B2-N

Peabody Journal of Education is currently published by Lawrence Erlbaum Associates, Inc..

Your use of the JSTOR archive indicates your acceptance of JSTOR's Terms and Conditions of Use, available at http://www.jstor.org/about/terms.html. JSTOR's Terms and Conditions of Use provides, in part, that unless you have obtained prior permission, you may not download an entire issue of a journal or multiple copies of articles, and you may use content in the JSTOR archive only for your personal, non-commercial use.

Please contact the publisher regarding any further use of this work. Publisher contact information may be obtained at http://www.jstor.org/journals/leb.html.

Each copy of any part of a JSTOR transmission must contain the same copyright notice that appears on the screen or printed page of such transmission.

JSTOR is an independent not-for-profit organization dedicated to and preserving a digital archive of scholarly journals. For more information regarding JSTOR, please contact support@jstor.org. 


\title{
Culture and Moral Leadership in Education
}

\section{Kam-cheung Wong}

\begin{abstract}
I begin by arguing that East Asia is different from the West in many aspects and that the main contributing factor is societal culture. Only recently have scholars in the field of educational administration begun to pay attention to societal culture as a theoretical construct for the analysis of educational theories. The emerging theme of moral leadership that Sergiovanni, Greenfield, and others in the West discuss is consonant with a long intellectual tradition in Chinese culture. The Chinese have a history of both valuing moral leadership and preparing leaders on moral grounds. I examine the early Confucian thought on moral leadership and suggest how the Chinese experience could provide additional examples of how scholars might conceive of moral leadership in modern times.
\end{abstract}

In the field of educational administration, the use of societal culture as a theoretical construct for the analysis is a recent phenomenon, albeit one with increasing significance. In this article, I draw on culture as a framework for analyzing leadership. More specifically, I focus on the concept of moral leadership, a mode of leadership that has received considerable attention in American education in recent years (Sergiovanni, 1990, 1992). I reconsider

Kam-CHEUng Wong is Associate Professor and Head, Department of Education, University of Hong Kong.

Requests for reprints should be sent to Kam-cheung Wong, Associate Professor and Head, Department of Education, University of Hong Kong, Pokfulam, Hong Kong. E-mail: kcwong@hkucc.hku.hk 
this construct in the light of a long tradition of moral leadership in Chinese culture.

I begin by arguing that East Asia is different from the West in many aspects and that the main contributing factor is culture. In a broad brush, I trace the origin of some of these differences. I argue that even at the beginning of contact between the cultures of the East and West, the concerns of the Chinese were already clearly distinguishable from those of the Greeks. The subsequent development of these cultures in separation set the differences even further apart in numerous dimensions. I offer reasons for the differences; I adopt a perspective of description and exploration, rather than judgment. ${ }^{1}$

In the second part of the article, I deal with the theme of moral leadership. I present Western conceptualizations of moral leadership and discuss them in light of the intellectual traditions of Chinese culture. The Chinese have a long history of valuing moral leadership and also of preparing leaders on moral grounds. I recount early Confucian thought on moral leadership and suggest how the Chinese experience illuminates other dimensions of thinking about moral leadership in the modern global age.

\section{Matter of Culture}

Elsewhere, Wong $(1996,1997)$ traced the origin of the development of early Chinese societies and attempted to group these differences according to several analytic categories (see Table 1). These dichotomies between Chinese and Western (Greco-Roman, Judeo-Christian) cultures run the risk of oversimplifying the issue $;^{2}$ however, they do describe the extensive differences that have been noted in the literature. These cultures developed in separation from one another. The geographical environment prevented China from contacts with other civilizations for a long period of time. Thus, each has developed unique features over the centuries.

The Chinese, by virtue of culture, are different from Westerners in many significant aspects of daily life. It has been established, for example, that early Chinese scholars were not interested in pure abstract thinking. When

\footnotetext{
${ }^{1}$ One needs to point out that although there are differences, the societies of East Asia and the West are not static. The volume of contact between East Asians and Westerners through various means of communications in the modern time indicates that mutual influences are not only possible, but take place all the time.

${ }^{2}$ For example, it was pointed out that under Western culture, there is also the school of thought that emphasized humanism after the Renaissance. The table does, however, represent only the characteristics of the mainstream of thought.
} 
Table 1

Comparison of Chinese and Western Cultures

\begin{tabular}{lll} 
Philosophical/Cultural Aspect & Western Culture & \multicolumn{1}{c}{ Chinese Culture $^{\mathrm{a}}$} \\
\hline Thinking method & Logical-analytical & $\begin{array}{l}\text { Synthetic } \\
\text { Dialectic } \\
\end{array}$ \\
Epistemological aspect & Scientific & Metaphysical \\
& Knowledge-based & Inner moral \\
Ontological aspect & Nature & Life \\
Cultural aspect & Realistic & Pragmatic \\
& Individual ability & Community-related effort \\
Religious aspect & Monotheistic & Indifferentist (neutralist) \\
\hline
\end{tabular}

${ }^{\mathrm{a}}$ The arguments here are based on views of the neo-Confucian school of thought.

they came across abstract ideas, they always expressed them in terms of concrete or visual objects. Instead of saying "fast," the Chinese would say "thousand-mile horse" (the horse could cover a thousand miles in a relatively short time).

For the concept of "old," the Chinese had three different ways of expression: one was "sixty years," another one was "seventy years," and a third one was "eighty or ninety years." Likewise, instead of using a general word such as "death," the Chinese used five different concrete expressions to reflect a hierarchy of death: for the king, the royalty, the official, the intellectual, and the common folk.

The ancient $C$ hinese were also not interested in spiritual beings. This was reflected in the works of Confucius. When Chi-lu, one of Confucius' disciples, asked about serving spiritual beings, Confucius answered that if we did not yet know about life, we could not know about death (The Analects, 11:11; quoted in Chan, 1963).

Some claim that these habits of the Chinese to conceptualize ideas in concrete (particular) objects and to adopt a pragmatic attitude toward life have constrained development of their abilities in generalization and imagination (Xu, 1991). Chan (1963), for example, argued that all major ancient Chinese philosophers were primarily concerned with "the relationship between names and actuality" (p. 232). In Confucianism this took on social and moral significance. In Taoism, its import was primarily metaphysical. In Legalism, its function was political control.

None were interested in the overt logical consideration of problems. Mou (1987) asserted that a primary characteristic of the Chinese philosophy is its focus on "subjectivity" and "inner morality." This differs from the Greek tradition, in which philosophers sought to understand the universe through 
logic (e.g., Aristotle). Logic remains highly influential in the training of the Western mind to this day (Russell, 1961).

For example, the writings of Lao-tsu are considered crucial in understanding Chinese philosophy (Chan, 1963). It is not accidental that his work is full of dialectical, seemingly contradictory expressions. He frequently couched arguments in oppositional phrases: "To yield is to be preserved whole," "To bend is to become straight," "To be empty is to be full; ... to have little is to possess," "... because he does not compete, the world cannot compete with him."

This is not to say that the Chinese could not be logical and analytic. The ancient Chinese thinkers simply were not interested in pure logical and analytic thinking per se. There were logicians in the early days, but the school was very small and never developed into a line of influential scholarship.

Take Hsun-tsu, a follower of Confucius, as an example. ${ }^{3}$ Hsun-tsu's thinking comes closer to the Western mind in his emphasis on knowledge and logical analysis. Even so, his concern was still very much moral and social. However, Hsun-tsu's writings, though quite substantial, were largely ignored after the Han dynasty (A.D. 200). It was not until the early 20 th century that modern writers began to seek a fuller understanding of his work.

The Chinese adoption of Buddhism from India provides another illustration of how the culture developed in a contrasting direction. The Indians were known for abstract thinking, as exemplified in their philosophy and in the Buddhist religion. The massive translation of Buddhist literature from India over several hundred years had a significant influence on the Chinese. However, it is notable that among the many schools of Buddhism imported from India, the only school that finally survived and became prominent in China is Zen (Ch'an).

In Zen Buddhism, one contemplates the abstract concept of Truth-Reality (Thusness). The Chinese adapted this and refocused attention on the "mind." This was consistent with traditional Chinese philosophy (Chan, 1963). The effect of Zen is to minimize, if not wipe out, the basic Buddhist organization, creed, and literature. In the words of Japanese Zen scholar Suzuki (1953), the Zen movement in China demonstrates how "the Chinese mind completely asserted itself, in a sense, in opposition to the Indian mind.

\footnotetext{
${ }^{3}$ Hsun-tsu held a totally different view regarding the nature of human from Mencius, another follower of Confucius. Hsun-tsu argued that humans were by nature evil, and hence needed to be educated, whereas Mencius believed that humans were intrinsically good and that individuals had to preserve the goodness in themselves.
} 


\section{K. C. Wong}

Zen could not have risen and flourished in any other land or among any other people" (p. 40).

Likewise, one could argue that the emphasis on the nature of knowledge (epistemology) and the nature of being (ontology) are characteristic of Western thinking. The early Chinese philosophers were simply not interested in understanding nature. Prominent Chinese philosophers such as Lao-tsu and Chuang Tsu advocated living in harmony with nature, not in understanding it. Confucius emphasized moral training of character and the restoration of the ancient rites. They were preoccupied with the practical aspects of life and knowledge. This and their disinterest in purely abstract thinking were reasons why they never developed "theories of knowledge" as in the Western works of Plato, Aristotle, Descartes, and Kant.

Another reason was their preoccupation with state office. Under the influence of Confucianism, many Chinese scholars considered it their obligation to serve the state. Partly this grew out of necessity. Following the Han dynasty, the Chinese states developed a system that absorbed scholars into the civil service. After the Tang dynasty, this was fostered through a sophisticated system of national examinations.

Subsequently and for a very long period of time, joining the civil service was the only recognized outlet of scholarly expression. Johnson (quoted in Fairbank, 1994, p. 83) commented that in the Europe of the past a man could rise to a position of high social status through a career in law, medicine, commerce, the Church, or the military. In China there was only one significant occupational hierarchy: the civil service.

Chinese philosophy did not emphasize logical-analytical thinking. This did not hinder the technological development of the Chinese society or culture. In fact, the ancient Chinese developed a great deal of technical skills and knowledge. They developed technologies in silk and porcelain making, printing, manufacture of gunpowder, and use of the compass well ahead of European societies (Needham, 1995). Up to the 15th century, Chinese technology still led the world in many intellectual and technical domains.

Subsequently, however, Western Europe went through more rapid evolution: the Renaissance, the scientific revolution and the Enlightenment, the Industrial Revolution, and the rise of capitalism. Modern Western civilization began to exert its influence on the rest of the world, and other civilizations, including the Chinese, were marginalized. This remained the same until the last decades of the 20th century when East Asian economies began to outperform the industrialized West. ${ }^{4}$

\footnotetext{
${ }^{4}$ This was the case until the recent currency crisis of some East Asian countries. It is expected that the crisis will slow down the economic development of the countries in the region.
} 
In terms of religious belief, the Chinese were also known for their tolerance of different faiths. Many Chinese hold the belief that all religions are of equal validity. This tolerance of ambiguity in religion is quite remarkable. Most Westerners would find it difficult to comprehend the possibility of practicing two religions simultaneously-never mind actually doing it. How could they be both Roman Catholic and Protestant? Nor is it viable for them to follow Christianity and Buddhism at the same time. Yet this is quite a common practice among Chinese in East Asia.

\section{Impact of Culture on Managerial Norms}

In the last two decades, more and more scholars from cross-cultural psychology and philosophy have called attention to and tried to account for the differences between the West and East Asia, in particular with the Chinese. These wide and significant differences in behavior are reported in the research of Hampden-Turner and Trompenaars (1997) and others. They provide empirical findings to convincingly argue that culture makes a difference in common patterns of behavior, ways of thinking, and approach to life (Allinson, 1989; Hofstede, 1980; F. L. K. Hsu, 1985; Watkins \& Biggs, 1996). In assessing this comparison, Liu (1988) remarked that these cultural differences were as if created deliberately by God for a contrast.

Hofstede (1980) is acknowledged as breaking the ground in terms of inquiry into culture and management. Recent empirical work by HampdenTurner and Trompenaars (1997) built on his earlier theoretical and empirical findings. In their book Mastering the Infinite Game (1997), they surveyed over 30,000 middle and senior managers from 58 countries. They explored the work-related values of managers in different countries.

Hampden-Turner and Trompenaars (1997) discovered that North American and West European managers were clearly distinguished from their counterparts from East Asia. Differences were revealed on a number of theoretical value-related dimensions. They provide empirical support for the popular contention that there do exist a set of "Asian values."

For example, on the value of cooperating versus competing, they constructed contrasting value-related variables. While the practices of North American and West European managers tend to be grounded in certain values, the beliefs and practices of East Asian managers reflect a very different set of assumptions. Hampden-Turner and Trompenaars (1997) found that Western managers quite consistently adopted a more competitive, individualistic, goal-directed, rule-based approach than East Asians. East Asians were guided more by communitarian, social-external, consensus-based norms in their managerial styles. 


\section{K. C. Wong}

Interestingly, Hampden-Turner and Trompenaars (1997) also found that East Asian managers are more adaptive than those in the West. They tend to learn Western values and to utilize Western technologies. In the process, they seek to reconcile their own cultural values with those of the West. This learning process begins relatively early; many Eastern managers graduate from Western universities. The socialization process continues as they work in multinational corporations or in organizations where Western management approaches are influential.

Furthermore, the cultural norms of their societies appear to aid Asian managers in this socialization process. Traditional Taoist, Confucian, and Buddhist philosophies all teach the complementarity of human processes. This tends to open Easterners to the possibility of reconciling alternate values. Notably, however, the same does not appear to hold true for many of their Western counterparts, who see the world in either-or terms (Hampden-Turner \& Trompenaars, 1997).

This cultural difference finds expression in schools as well. Cheng and Wong (1996) studied school effectiveness in East Asia in an attempt to uncover cultural dimensions of successful educational practice. They set up three dichotomies to account for Chinese differences from Westerners in their attitudes toward learning and schooling: individual-community, ability-effort, and holistic-idealistic. These were useful in describing how these differences still affect education and the life of many ethnic Chinese in modern East Asian societies.

\section{The Cultural Issue in Education}

Administration and Leadership

In educational administration and leadership, attention to societal culture as an analytical frame is a relatively recent development. One could perhaps attribute the origin of this development of the debate on values in educational administration to the seminal works of Greenfield $(1986,1987)$ and Hodgkinson (1991). Cheng (1995) was among the first international scholars in the field to call attention to the neglect of the (societal) cultural dimension in educational administration. ${ }^{5}$ Hallinger (1995), Hallinger and Leithwood (1996), and Bajunid (1996) separately identified (societal) culture as a missing factor in educational leadership theory. These authors explicitly advocated the study of how educational leadership is enacted in and influenced by societal cultures.

${ }^{5}$ Cheng (1995) first published his view in the Regional Conference of the Commonwealth Council of Educational Administration held in Hong Kong in 1992. 
In the mainstream of educational administration theory, culture refers mainly to organizational values and rituals that provide people with a sense of meaning and continuity (see, e.g., Deal \& Kennedy, 1982). An example is the recent writing by Duke (1996). When he deliberated on the cultural dimension of organizational leadership, he focused attention only on the cultures that exist within organizations.

It is not that societal culture has never been suggested in theory. Hallinger and Leithwood (1996) pointed out that as early as the 1960s, Getzels and his colleagues had developed comprehensive conceptualizations of educational leadership and located the administrator and the educational institution in a cultural context: "Getzels and his colleagues discussed also at length the varying impact that different cultural values could exert on the thinking and behavior of leaders" (p. 102). However, they further noted that the initial theoretical work of Getzels has been followed by neither additional theoretical exploration nor empirical study in educational administration.

Hallinger and Leithwood (1996) observed that in the Western management tradition, societal culture is often treated as an "implicit variable." This neglect of societal culture reveals the underlying assumption that theories developed within a given culture, particularly the intellectually dominant one, have universal application. This appears to be a commonly held, if implicit, perception shared by many Western scholars in management.

\section{Values and Leadership Theory}

There has been a recent call for strong leadership in private sector organizations as well as in schools (Bennis \& Nanus, 1985; Bottery, 1992; Fullan, 1995; Sergiovanni \& Corbally, 1986; Yukl, 1994). This has been apparent not only in the West, but also in Asian societies. For example, the Hong Kong Education Department (Education and Manpower Branch and Education Department, 1991) recently unveiled the School Management Initiative. This is a school-based management scheme that portrays the school leader as someone who should possess an impressive array of technical and cognitive skills. These include:

- Professional knowledge.

- Organizational and administrative competence.

- Ability to work out a good school policy and put it into effect.

- Skill in the delegation of authority.

- Ability to understand the professional problems of teachers, especially young and inexperienced teachers, and to give professional guidance. 


\section{K. C. Wong}

- Ability to establish good working relationships with staff and parents. (Education and Manpower Branch and Education Department, 1991, p. 14)

Despite the fact that this initiative mirrors a global trend toward strong leadership in organizations, another school of thought has questioned this approach in schools. Advocates argue against an overreliance on structure and control in leading modern organizations. This school of leadership thinking has utilized the concepts of values and social-moral relations among people in its critique of traditional leadership theories (Blumberg, 1989; Bottery, 1992; Cunningham \& Gresson, 1993; Greenfield, 1987; Hodgkinson, 1991, 1996; Senge, 1990; Sergiovanni, 1991; Sergiovanni \& Corbally, 1986).

For example, Senge (1990) claimed that traditional views of leaders are deeply rooted in an individualistic and nonsystemic worldview. In this worldview, leaders are heroes. They are great men (and occasionally women) who "rose to the fore in difficult times and crises... The prevailing leadership myths are still captured by the image of the captain of the cavalry leading the charge to rescue the settlers from the attacking Indians" (p. 340). This has been the case in education as many have called for principals to lead the charge toward more effective schools.

Sergiovanni (1992), among others, argued against the leadership theory which emphasizes rationality, logic, objectivity, explicitness, individuality, and detachment. He advocated theory that emphasizes emotions, group membership, sense making, meaning making, morality, duty, and obligation. Cunningham and Gresson (1993) similarly argued that informal rules and norms which represent the culture of the organization best explain how people conduct their work lives.

A reliance on structural and behavioral components in traditional leadership theories has not been without its success. Over the past century, it has fostered the capacity of school systems to achieve moderate levels of competence. Educational systems throughout the world have grown and been maintained through the use of basic bureaucratic administrative principles.

However, Sergiovanni and others question whether such approaches are sufficient to bring about excellence in schooling. The managerial norms of efficiency, specificity, rationality, measurability, and objectivity have created a myth that good management is necessarily "tough minded." This has been the essence of the mainstream management in the West. A good administrator is someone who is rational, plans ahead, monitors, manages with certainty, and can back up decisions with logical arguments. These capaci- 
ties are, however, far from sufficient to address the complexity of life in modern schools.

In contrast, values-based leadership theory focuses on the human dimensions of organizations. Greenfield (1986), for example, contended that schools, like people, are unique entities. This uniqueness is better captured by the notion of school culture than by a depiction of structure and policy. Greenfield believed schools were better understood in context, from a set of concrete events and personalities, than from a set of abstractions or general laws (p. 143).

This suggests an approach to leadership that seeks to build shared vision and goals within a community of people. A values-based mission binds leaders and followers into a shared covenant (Sergiovanni, 1991; Sergiovanni \& Corbally, 1986; Vaill, 1986). Values-based leadership influences the culture of the organization and, advocates contend, is better equipped to bring about lasting change.

\section{Moral Leadership}

Moral leadership is a concept that has been developed by a number of authors (Etzioni, 1988, 1993; Greenfield, 1986; Hodgkinson, 1991, 1996; Sergiovanni, 1991, 1992, 1996). They argued that schools are civil associations, and as such differ fundamentally from enterprise associations like corporations. What is suitable for corporations may be highly inappropriate for schools. Schools carry with them a moral obligation in their responsibility for the education of a society's youth (Goodlad, Soder, \& Sirotnik, 1990; Greenfield, 1995).

I argued in the previous section that schools are civil associations and that they differ from enterprise corporations in important respects. For example, schools differ from corporations in their ultimate purposes. Corporations pursue profit goals and use these to select strategic activities and work processes. In other words, whether a corporation chooses to adopt participatory decision making will depend on the degree to which managers believe it will contribute to profits. In contrast, educators often advocate democracy as a desirable and appropriate way of life in schools on moral grounds unrelated to outcomes such as student achievement. In this context, schools may choose to adopt the participatory decision-making process because they are consistent with this underlying purpose (Wong, 1993).

Goodlad et al. (1990) argued strongly that "teaching the young has moral dimensions ... because education-a deliberate effort to develop values and sensibilities as well as skills-is a moral endeavor" (p. xii). There are 


\section{K. C. Wong}

numerous instances in which school heads and teachers are called on to make decisions that have moral implications. For example, schools decide whether to suspend a student from lessons because of disturbing behavior in the classroom-a rather common event in Hong Kong school settings. Here the student's behavior is at stake (from the viewpoint of the school) and it is considered, in the local context, the schools' obligation to improve the behavior of students.

Decisions of this nature have implications for both students and teachers. On the one hand, the student is expected to learn from the mistake and improve. But schools do not always achieve this outcome because in many cases the students do not feel that the punishment is for their improvement. The school must judge whether or not such a decision will likely benefit the student. There is also the need to work out a relationship with the student so that he or she sees the mistake more readily and will work to improve. Leaders must establish a trusting relationship between students and the school (the teachers and head).

In many cases, schools are also smaller than corporations in size. Because of size, corporations are more inclined to engage in bureaucratic management. In schools, the smaller scale may allow a more personal approach in leadership. Such a differentiation in management is also seen in comparisons between primary and secondary schools. Smaller size makes the leader's personal influence more directly felt. It is usually the case that the head interacts with teachers quite regularly in schools, making their examples more readily observable. This is perhaps why small schools have been advocated in the literature (e.g., Sergiovanni, 1996).

\section{Sergiovanni's Conceptualization of Moral Leadership}

Heifetz (1994) argued that a leader must "take sides" in the exercise of leadership. Leadership is therefore subjective and normative. Sergiovanni distinguished between several conceptualizations of leadership: bureaucratic, psychological, rational-technical, professional, and moral. According to Sergiovanni (1992), bureaucratic styles of leadership rely on mandates, rules, regulations, job descriptions, expectations, and outcomes as a means of monitoring and controlling staff and students. Hence bureaucratic leadership occupies the lowest stage of moral development.

Even psychological leadership, which draws its authority from motivation and human relations skills, is similarly transactional in nature. It focuses on control and advocates the spirit of "what gets rewarded gets done." Sergiovanni (1992) argued that given what we know about how 
schools really work, psychologically based leadership should not enjoy such a prominent position. In his words, it

cannot tap the full range and depth of human capacity and will. It cannot elicit the kind of motivated, spirited response from parents, teachers, and students that will allow schools to work well and students to become fully functioning persons (p. 33).

Sergiovanni (1992) also critiqued leadership based on technical-rational authority. Technical-rational authority of leadership is derived from social science, and for this reason is highly prized in society. He argued, however, that teaching and learning are human activities that are too complex to be reduced to rules and procedures-even purportedly scientific ones. Technical-rational leadership assumes that expertise can be reduced to a knowledge base that exists apart of the complexity of the teacher as a person and even from the actual practice of teaching. Sergiovanni believed that teaching practice is too idiosyncratic, nonlinear, and loosely connected to student outcomes to be standardized in a manner that lends itself to rational-technical leadership.

Sergiovanni (1992) contended that a higher level of leadership authority is to be found in the professional and moral domains. When professional authority becomes a driving force, leaders rely on standards of practice and professional norms as reasons to appeal to teachers for action or change ( $p$. 40). In Moral Leadership, Sergiovanni (1992) recounted stories of successful school leaders who were intimately involved in classrooms with students and teachers. Built on his own research, as well as the work of others (e.g., Blumberg, 1989; Etzioni, 1964, 1988; Johnson, 1990; Lewis, 1990; Lortie, 1975; Mintzberg, 1987), Sergiovanni $(1992,1996)$ put forward the proposition that people are by nature morally responsive and are capable of responding to duties and obligations that stand above their own self-interest.

This moral proposition of Sergiovanni is consistent with Burns's (1978) transformational leadership and Maslow's (1954) higher level of needs. According to Burns, transactional leadership focuses on basic and largely extrinsic motives and needs. Transformational leadership appeals to higher order, intrinsic, moral motives and needs. The transformational leader elevates followers to a higher moral level (Burns, 1978; Hodgkinson, 1996; Sergiovanni, 1991).

The sources of leadership authority of Sergiovanni (1992)-Maslow's (1954) hierarchy of needs and Burns's (1978) leadership model—could be integrated into a cohesive picture as in Table 2. This moral proposition is also consistent with the latest management thinking. This calls for participation, collaboration, collegiality, enabling and empowerment, and above 


\section{K. C. Wong}

Table 2

Integration of Hierarchy of Needs, Sources of Leadership, and Leadership Model

Maslow's Hierarchy of Needs $\quad \begin{gathered}\text { Sergiovanni's Source } \\ \text { of Leadership }\end{gathered} \quad$ Burns's Leadership Model

High-level needs

(Righteousness, obligation)

Self-actualization

Esteem

Moral authority

Transformational

Low-level needs

Love

Professional authority

Technical-rational

authority

Safety

Psychological authority

Physiological

Bureaucratic authority

all, building a trusting relationship within organizations (Peters \& Waterman, 1982; Rosenholtz, 1989; Vaill, 1986; Yukl, 1994).

The moral leadership proposed by Sergiovanni carries dual implications. The first suggests that the leader must appeal to the followers' sense of righteousness, obligation, and goodness as motivations for action and work. The second implication is that the leader must possess a sense of righteousness, obligation, and goodness himself or herself. Without this, it is difficult to conceive how followers could be motivated to follow a moral path. Hence, to argue for a moral dimension of leadership implies a moral standing on the part of the leader.

Sergiovanni's conceptualization of moral leadership begs many questions and has been critiqued. Defining righteousness and goodness in practical terms assumes agreement on values. Angus (1989) challenged the moral leadership concept in light of the frequent business fraud, tax evasion, cheating, diversion of funds, and scandals in high places. That is, leadership as described on moral grounds often fails the test. Finally, Maxcy (1991) asserted that a model of moral authority that relies on private moral conscience is itself problematic, unless it is checked by a democratic cultural consensus.

\section{Moral Leadership in the Traditional Chinese Perspective}

Discussions of moral leadership have only recently gained popularity in the West. This notion, however, resonates with traditional Chinese thinking about leadership, if not necessarily with practice in the present. In this part of the article, I examine early Chinese thinking, particularly Confucian views on moral leadership. 
Chinese culture has a long history of cultivating leadership on moral grounds. When the Chinese turned to the West for modernization in the last century, however, they gradually adopted Western models of social and political organization. Gradually, many traditional values have been rejected or adapted into hybrids.

This was particularly pronounced in the New Cultural Movement in 1915 (4 years later came the famous May Fourth Movement). Leaders publicly denounced the written system and the culture of the past, in particular Confucianism (Fairbank, 1994; I. C. Y. Hsu, 1975). As a result, since that period Chinese culture has suffered great confusion (Qian, 1979; $\mathrm{Yu}, 1982 \mathrm{a})$. Despite this departure from the past, cultural values change slowly. Thus, what we refer to as traditional Chinese values are still influential in many Chinese societies today.

\section{Emphasis on Ethical Humanism in Chinese Culture}

Many Western scholars view China as a civilization that did not pass through a childhood of dreams and heroic exploits. Rather, it seemed to simply appear from the beginning with a full-grown humanistic face (Kung \& Ching, 1989). Indeed, a school of ethical humanism developed very early in the Chinese civilization. Chan (1963) asserted that Chinese philosophy, starting as early as the Chou dynasty (1111-249 B.C.), was dominated by ethical humanism. This school of thought places great emphasis on people and their activities in the world.

Since the Chou dynasty, the spiritual force was replaced by the Mandate of Heaven. This is a moral law whose constant factor is virtue. In this light, humanity's destiny is linked to his own good words and deeds. It is not based on the existence of a soul, nor on the whim of a spiritual force, as in Greek tradition.

For example, the founders of the Chou dynasty justified their right to rule by asserting that the prior rulers had forfeited their mandate to rule by failing in their ethical duties to their subjects. The mandate, therefore, passed to the Chou, who deserved it because of their virtue. The future of the Chou dynasty would depend on the capacity of the Chou rulers to live up to this ethical mandate (Chan, 1963).

Ethical humanism reached its climax in Confucius. He focused almost exclusively on human activities, paying little attention to spiritual beings. When Fan Chih, a disciple, raised a question concerning the nature of wisdom, Confucius replied: "Devote yourself earnestly to the duties due to men; respect spiritual beings but keep them at a distance. This may be called wisdom" (The Analects, 6:20; quoted in Chan, 1963, p. 30). Keeping spiritual 


\section{K. C. Wong}

beings at a distance and at the same time giving full attention to human activities have become distinctive characteristics of the Chinese culture (Kung \& Ching, 1989).

\section{Emphasis on Learning}

What we think of as traditional Chinese culture is dominated by Confucian thinking. ${ }^{6}$ Confucius was the first to open the door of education to all. For him, education had no class distinction. Confucius once commented that he would never reject anyone who wanted to learn, even someone who came with as little as a bit of dried meat for tuition. Hence among his pupils there were commoners, merchants, nobles, and dull as well as intelligent people. This was a real revolution, because prior to Confucius education was confined to nobles and controlled by officials.

Confucius laid great emphasis on learning. The theme of learning is repeated on numerous occasions in Confucius' dialogues with his disciples: "Is it not a pleasure to learn and to practice from time to time what has been learned?" (The Analects, 1:1; quoted in Chan, 1963, p. 18).

Confucius also advised people to review the old so as to find out the new in their studies (The Analects, 2:11; quoted in Chan, 1963, p. 23). He believed that by nature men were alike, and it was through learning and practice that they become differentiated. This theme was further developed by Mencius, who laid the foundation for the Confucian philosophy developed in the Ming and Sung dynasties (Chan, 1963).

Confucius' pragmatic attitude toward life and his emphasis on learning has had tremendous influence on the mind of the Chinese. The Chinese subsequently have become known for the value they place on effort and education. Behind this emphasis lies the assumption, expounded by Confucius, that everyone can succeed if one works hard. This was further reinforced by the relation, discussed earlier, between scholarship and the civil service. This supported the Confucian tradition that encouraged scholars to apply what they had learned to serve the states.

\section{Moral Aspect of Learning}

Despite his pragmatism, in Confucius' eyes learning does not primarily serve a vocational purpose. Its function lies in character training: learning

\footnotetext{
${ }^{6}$ Confucian thinking had absorbed many ideas from Taoism and Buddhism throughout the centuries. The influence of Zen Buddhism was particularly renounced since it had stimulated the renewal of Confucianism after the Sung dynasty.
} 
to be conscientious (chung) and altruistic (shu; Chan, 1963, p. 17). For Confucius, it is insufficient if one keeps learning to himself:

Man of ethical humanity [man of benevolence] must also practice what he has learnt. When he wishes to establish himself, he must at the same time establish the others. When he wishes to be prominent, he must also help others to be prominent (The Analects, 6:28; quoted in Chan, 1963, p. 31).

This is the Confucian golden rule (Chan, 1963). Hence, learning for Confucius carries two purposes. The first is to learn to be an upright, moral person. This is the ideal of the gentleman (chun tsu), or the superior person. Being a moral person, the scholar needs to possess a number of virtues including benevolence, duty, observance of rites, wisdom, courage, and reliability (Lau, 1988). The scholar must be able to link learning with wisdom, humanity, and courage (The Doctrine of the Mean; quoted in Chan, 1963, p. 105).

After the first purpose of learning has been accomplished, then it is possible to apply what has been learned to serve the people. Learning for Confucius has always had an external motive. When Tsu-lu, (a disciple of Confucius) asked about the nature of a gentleman, Confucius said, "The gentleman is one who cultivates himself with seriousness." Tsu-lu replied, "Is that all?" Confucius said, "He cultivates himself so as to give the common people security and peace." Tsu-lu said, "Is that all?" Confucius said, "He who cultivates himself so as to give all people security and peace" (The Analects, 14:15; quoted in Chan, 1963, p. 3).

Confucius himself spent part of his early life in travel to persuade the states to accept his ideas. To be able to serve the state is considered a moral obligation of the scholar. Serving the state follows an order that links the two purposes of learning.

The order starts first from the self, extends to one family and then to the states. This was well put in The Great Learning:

The ancients who wished to manifest their clear character to the world first bring order to their states. Those who wished to bring order to their states would first regulate their families. Those who wished to regulate their families would first cultivate their personal lives. Those who wished to cultivate their personal lives would first rectify their minds. Those who wished to rectify their minds would first make their will sincere. Those who wished to make their will sincere would first extend their knowledge. The extension of knowledge consists in the investigation of things. (The Great Learning; quoted in Chan, 1963, p. 86) 


\section{K. C. Wong}

Ultimately, serving the state became one of the main purposes for learning. This produced the "scholar-gentry"-a unique social class in the Chinese society. Yu (1982b) traced and recorded the influence of the scholargentry class, particularly the scholar-officials in the spread of Confucian value. Inevitably these scholar-officials regarded themselves more as teachers than civil servants and carried out the teaching of Confucius. In the 400-year rule of the Han, they succeeded to make many of the Confucian practices part of the popular culture.

\section{Conclusion}

Moral leadership focuses quite directly on articulating and upholding important school values. Through a focus on values and behavioral norms of the school rather than on rules, regulations, and policies, moral leaders can potentially create a stronger impact on the life of teachers and students. (I must point out here that moral leadership is not to replace rules, regulations, and policies, but to supplement and enrich them.) As such, moral leadership could be both a motivating and stabilizing factor in sustaining the performance of schools. This is an issue of immense interest in the literature of effective school studies, where lasting improvement often eludes school management.

In this article, I have tried to connect moral leadership in schools as discussed by Western analysts with a longer tradition in Chinese society. In focusing on this issue, I sought to demonstrate how the construct of moral leadership has a strong grounding in the intellectual traditions of East Asia, particularly China. Although the scope of this article was limited to description in the two contexts, I hope that this analysis will stimulate interest of others in looking cross-culturally at this and other phenomena in educational leadership and administration.

\section{References}

Allinson, R. E. (1989). Understanding the Chinese mind: The philosophical roots. New York: Oxford University Press.

Angus, L. (1989). New leadership and the possibility of education reform. In J. Smyth (Ed.), Critical perspectives on educational leadership (pp. 63-92). London: Falmer.

Bajunid, I. A. (1996). Preliminary explorations of indigenous perspectives of educational management: The evolving Malaysian experience. Journal of Educational Administration, 34(5), 50-73.

Bennis, W., \& Nanus, B. (1985). Leaders: Strategies for taking charge. New York: Harper \& Row. Blumberg, A. (1989). School administration as craft. Needham Heights, MA: Allyn \& Bacon.

Bottery, M. (1992). The ethics of educational management. London: Cassell.

Burns, J. (1978). Leadership. New York: Harper \& Row. 


\section{Culture and Moral Leadership in Education}

Chan, W. T. (Trans. and Compiler). (1963). A source book in Chinese philosophy. Princeton, NJ: Princeton University Press.

Cheng, K. M. (1995). The neglected dimension: Cultural comparison in education administration. In K. C. Wong \& K. M. Cheng (Eds.), Educational leadership and change: An international perspective (pp. 87-104). Hong Kong: Hong Kong University Press.

Cheng, K. M., \& Wong, K. C. (1996). School effectiveness in East Asia: Concepts, origins and implications. Journal of Educational Administration, 34(5), 50-73.

Cunningham, W. G., \& Cresson, D. W. (1993). Cultural leadership: The culture of excellence in education. Needham Heights, MA: Allyn \& Bacon.

Deal, T., \& Kennedy, A. (1982). Corporate cultures: The rites and rituals of corporate life. Reading, MA: Addison-Wesley.

Duke, D. L. (1996). Perception, prescription and the future of school leadership. In K. Leithwood, J. Chapman, D. Corson, P. Hallinger, \& A. Weaver-Hart (Eds.), International handbook of research in educational leadership and administration (pp. 841-871). Dordrecht, The Netherlands: Kluwer.

Education and Manpower Branch and Education Department. (1991). The School Management Initiative: Setting the framework for quality in Hong Kong schools. Hong Kong: Hong Kong Government Press.

Etzioni, A. (1964). Modern organizations. Englewood Cliffs, NJ: Prentice Hall.

Etzioni, A. (1988). The moral dimension toward a new theory of economics. New York: Free Press.

Etzioni, A. (1993). The spirit of community rights, responsibilities and the communitarian agenda. New York: Crown.

Fairbank, J. K. (1994). China, a new history. Cambridge, MA: Belknap.

Fullan, M. (1995). The evolution of change and the new work of the educational leader. In K. C. Wong \& K. M. Cheng (Eds.), Educational leadership and change: An international perspective (pp. 15-28). Hong Kong: Hong Kong University Press.

Goodlad, J., Soder, R., \& Sirotnik, K. (1990). The moral dimensions of teaching. San Francisco: Jossey-Bass.

Greenfield, T. B. (1986). Leaders and schools: Willfulness and nonnatural order in Organization. In T. J. Sergiovanni \& J. E. Corbally (Eds.), Leadership and organizational culture: New perspectives on administrative theory and practice (pp. 142-169). Urbana: University of Illinois Press.

Greenfield, W. (1987). Moral imagination and interpersonal competence: Antecedents to instructional leadership. In W. D. Greenfield (Ed.), Instructional leadership (pp. 56-73). Boston: Allyn \& Bacon.

Greenfield, W. (1995). Toward a theory of school administration: The centrality of leadership. Educational Administration Quarterly, 31, 61.

Hallinger, P. (1995). Culture and leadership: Developing an international perspective in educational administration. UCEA Review, 36(1), 3-7.

Hallinger, P., \& Leithwood, K. (1996). Culture and educational administration: A case of finding out you don't know you don't know. Journal of Educational Administration, 34(5), 98-116.

Hampden-Turner, C., \& Trompenaars, F. (1997). Mastering the infinite game: How Asian values are transforming business practice. Oxford, England: Capstone.

Heifetz, D. A. (1994). Leadership without easy answers. Cambridge, MA: Belknap.

Hodgkinson, C. (1991). Educational leadership: The moral art. Albany: State University of New York Press.

Hodgkinson, C. (1996). Administrative philosophy: Values and motivations in administrative life. Elmsford, NY: Pergamon.

Hofstede, G. (1980). Culture consequences: International differences in work-related values. Beverly Hills, CA: Sage. 


\section{K. C. Wong}

Hsu, F. L. K. (1985). The self in cross-cultural perspectives. In A. Marsella, G. Devos, \& F. Hsu (Eds.), Cultural and self: Asian and Western perspectives (pp. 24-55). London: Tavistock.

Hsu, I. C. Y. (1975). The rise of modern China. Hong Kong: Oxford University Press.

Johnson, S. M. (1990). Teachers at work: Achieving success in our schools. New York: Basic Books.

Kung, H., \& Ching, J. (1989). Christianity and Chinese religions. New York: Doubleday.

Lau, D. C. (1988). Confucius: The Analects. Hong Kong: The Chinese University of Hong Kong Press.

Lewis, H. A. (1990). Question of values. New York: HarperCollins.

Liu, T. Y. (1988). Address at the Congregation for Honorary Doctorate Degrees. University of Hong Kong Gazette, 35, 1-2.

Lortie, D. C. (1975). Schoolteacher: A sociological study. Chicago: University of Chicago Press.

Maslow, A. H. (1954). Motivation and personality. New York: HarperCollins.

Maxcy, S. J. (1991). Educational leadership: A critical pragmatic perspective. Toronto: OISE Press.

Mintzberg, H. (1987). Crafting strategy. Harvard Business Review, 87(4), 66-75.

Mou, Z.-S. (1987). The characteristics of Chinese philosophy. Taiwan: Student Press.

Needham, J. (1995). The shorter science and civilization in China: History of scientific thought. Cambridge, England: Cambridge University Press.

Peters, T. J., \& Waterman, R. H. (1982). In search of excellence: Lessons from America's best-run companies. New York: HarperCollins.

Qian Mu. (1979). From Chinese history to understand Chinese race and culture. Taiwan: Student Press.

Qian Mu. (1985). History of Chinese thinking. Taiwan: Student Press.

Rosenholtz, S. (1989). Teacher's work: A social-organizational analysis. New York: Longman.

Russell, B. (1961). History of Western philosophy (2nd ed.). London: Routledge \& Kegan Paul.

Senge, P. T. (1990). The fifth discipline: The art and practice of the learning organization. New York: Doubleday.

Sergiovanni, T. J. (1990). Value-added leadership: How to get extraordinary performance in schools. New York: Harcourt Brace.

Sergiovanni, T. J. (1991). The principalship: A reflective practice perspective. Boston: Allyn \& Bacon.

Sergiovanni, T. J. (1992). Moral leadership. San Francisco: Jossey-Bass.

Sergiovanni, T. J. (1996). Leadership for the schoolhouse. San Francisco: Jossey-Bass.

Sergiovanni, T. J., \& Corbally, J. E. (Eds.). (1986). Leadership and organizational culture: New perspectives on administrative theory and practice. Urbana: University of Illinois Press.

Suzuki, D. (1953). Zen. A reply to Hu Shih. Philosophy East and West, 3, 25-46.

Vaill, P. (1986). The purposing of high performing systems. In T. Sergiovanni \& J. Corbally (Eds.), Leadership and organizational culture: New perspectives on administrative theory and practice (pp. 85-104). Urbana: University of Illinois Press.

Watkins, D. A., \& Biggs, J. B. (Eds.). (1996). The Chinese learners: Cultural psychological and contextual influences. Hong Kong: Comparative Education Research Centre \& the Australian Council for Educational Research.

Wong, K. C. (1993). School-based management, school effectiveness and the School Management Initiative: Different? How different? In A. Tsui \& I. Johnson (Eds.), Teacher education and development (Education Paper 19, pp. 45-58). Hong Kong: University of Hong Kong, Faculty of Education.

Wong, K. C. (1996). Is there a need to educate educational leaders in moral education? International Studies in Educational Administration, 24(2), 17-24.

Wong, K. C. (1997, April). Chinese culture and educational leadership: Its origin. Paper presented at the meeting of the American Educational Research Association, Chicago.

Xu, F.-G. (Trans.). (1991). The thinking method of the Chinese. Taiwan: Student Press. 


\section{Culture and Moral Leadership in Education}

Yu, Y.-S. (1982a). Chinese traditional thinking and its modern interpretation. Taiwan: Jieng Lun.

Yu, Y.-S. (1982b). The influence of the Han official on the spread of the Confucian culture. In Y.-S. Yu (Ed.), Chinese traditional thinking and its modern interpretation (pp. 167-285). Taiwan: Jieng Lun.

Yukl, G. (1994). Leadership in organization. Englewood Cliffs, NJ: Prentice Hall. 
http://www.jstor.org

\section{LINKED CITATIONS \\ - Page 1 of 1 -}

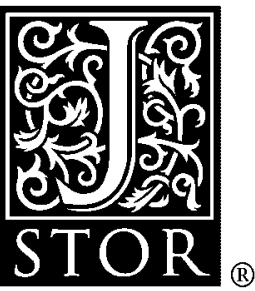

You have printed the following article:

\section{Culture and Moral Leadership in Education}

Kam-cheung Wong

Peabody Journal of Education, Vol. 73, No. 2, Leading Schools in a Global Era: A Cultural Perspective. (1998), pp. 106-125.

Stable URL:

http://links.jstor.org/sici?sici=0161-956X\%281998\%2973\%3A2\%3C106\%3ACAMLIE\%3E2.0.CO\%3B2-N

This article references the following linked citations. If you are trying to access articles from an off-campus location, you may be required to first logon via your library web site to access JSTOR. Please visit your library's website or contact a librarian to learn about options for remote access to JSTOR.

\section{References}

\section{Zen: A Reply to Hu Shih}

Daisetz Teitaro Suzuki

Philosophy East and West, Vol. 3, No. 1. (Apr., 1953), pp. 25-46.

Stable URL:

http://links.jstor.org/sici?sici=0031-8221\%28195304\%293\%3A1\%3C25\%3AZARTHS\%3E2.0.CO\%3B2-\%23 